\title{
Degradation of untreated and anhydrous ammonia-treated wheat straw by two strains of rumen anaerobic fungi
}

\author{
E Grenet 1 , A Bernalier 2, J Jamot 1, G Fonty 2 \\ 1 INRA Theix, station de recherches sur la Nutrition des herbivores, unité Ingestion, \\ 63122 Saint-Genès-Champanelle; \\ 2 INRA-Theix, laboratoire de Microbiologie, 63122 Saint-Genès-Champanelle, \\ and URA CNRS 138, laboratoire de Biologie comparée des protistes, \\ université de Clermont-Ferrand, 63170 Aubière, France
}

Anaerobic rumen fungi have the ability to hydrolyse cellulose and xylans of hemicelluloses, but little is known about the specific role of each species in the degradation of plant tissues. The aim of this study was to compare the degradation of untreated and anhydrous ammonia-treated straw by pure cultures of Piromyces (Piromonas) communis ( $\mathrm{FL})$, a species with filamentous rhizoids, and Caecomyces (Sphaeromonas) communis (FG10), a species with bulbous rhizoids.

The straw was prepared as described by Grenet and Barry (1990). The fungal cultures were carried out under $\mathrm{CO}_{2}$ in Bellco tubes in a semisynthetic medium in which the plant fragments were the sole energy source (Bernalier et al, 1991). The tubes for scanning electron microscope (SEM) observation contained small fragments of wheat straw and those for the measurement of DM disappearance $100 \mathrm{mg}$ wheat straw. Incubation times were 16, 24, 48, 72, 96 and $144 \mathrm{~h}$ at $39^{\circ} \mathrm{C}$.

In cultures of $P$ communis after $16 \mathrm{~h}$ of incubation, the phloem and the parenchyma were slightly degraded and rhizoids were visible on the surface of the plant fragments. After $24 \mathrm{~h}$ the mass of rhizoids on the surface of the plant fragments was so large that it was difficult to observe the underlying tissues. At this stage there was little change in the degradation of the parenchyma. After $48 \mathrm{~h}$ the inner parenchyma began to come away from the stem and zoospores were observed on the plant fragments. After $72 \mathrm{~h}$ the inner parenchyma had completely separated from the stem. $P$ communis degraded $15 \%$ of the untreated and $23 \%$ of the treated straw.

Sporocysts were attached to the sclerenchyma of wheat straw fragments incubated for $48 \mathrm{~h}$ in pure cultures of $C \mathrm{com}$ munis but there was little degradation. Likewise, after $72 \mathrm{~h}$ large numbers of sporocysts were observed but no clear degradation. After $96 \mathrm{~h}$ the sporocysts had also developed on the vascular bundles but no degradation was observed. The fungi were attached to lignified tissues. Only $7 \%$ of the untreated and $5 \%$ of the treated straw was degraded.

In conclusion, the ammonia treatment improved the degradation of the straw by $P$ communis but not with $C$ communis. The greater ability of $P$ communis in degrading the straw could be due to the presence of filamentous rhizoids, which are more effective than bulbous rhizoids at penetrating some types of plant tissues. However, the 2 fungi could also have different culture requirements.

Bernalier A, Fonty G, Gouet P (1991) Anim Feed Sci Technol 32, 131-136

Grenet E, Barry P (1990) Reprod Nutr Dev 30, 533-540 